\title{
Hybride und Chimären
}

\author{
Die Forschung an Mensch-Tier-Mischwesen aus verfassungsrechtlicher Sicht
}

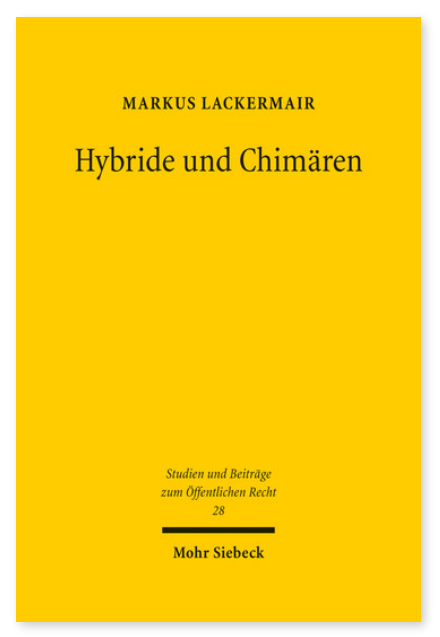

2017. XIV, 517 Seiten. StudÖR 28

ISBN 978-3-16-155087-4

DOI 10.1628/978-3-16-155087-4

eBook PDF 119,00€

ISBN 978-3-16-155048-5

Leinen $119,00 €$
Markus Lackermair widmet sich biomedizinischer Forschung, mit der Misch-Lebewesen aus Mensch und Tier erzeugt werden. So versuchen etwa Neurowissenschaftler, durch den Transfer menschlicher Gene die Gehirne von Tieren gezielt zu humanisieren. Ebenso motiviert der Mangel an menschlichen Spenderorganen die Transplantationsmedizin dazu, das Forschungsfeld der Xenotransplantation, d. h. der Verpflanzung tierischer Organe auf den Menschen, voranzutreiben. Dass durch derlei Experimente Mischwesen mit menschlichen und tierischen Bestandteilen zur Entstehung gelangen, zieht die in der Rechtsordnung etablierte strikte Grenzziehung zwischen Mensch und Tier in Zweifel. Die philosophischen Fragen Was ist der Mensch? Was unterscheidet ihn vom Tier? werden urplötzlich zu drängenden Rechtsproblemen mit konkreten Rechtsfolgen: Stellen solcherlei neuartige Mischwesen »Menschen« im Sinne der Rechtsordnung dar? Anhand welcher Kriterien ist dies jeweils zu entscheiden? Kommt Mischwesen Menschenwürde zu? Und vorgelagert: Dürfen solche Mischwesen überhaupt geschaffen werden?

Die vorliegende Dissertation wird mit dem Fakultätspreis 2016 der Juristischen Fakultät der Ludwig-Maximilians-Universität München ausgezeichnet.

Markus Lackermair Geboren 1986; Studium der Rechtswissenschaft an der Ludwig-Maximilians-Universität München; 2010 Erste Juristische Prüfung; Rechtsreferendariat im Oberlandesgerichtsbezirk München; 2012 Zweite Juristische Staatsprüfung; 2016 Promotion; seit 2015 Regierungsrat im Bayerischen Staatsministerium des Innern, für Bau und Verkehr.

Jetzt bestellen:

https://mohrsiebeck.com/buch/hybride-und-chimaeren-9783161550874?no_cache=1

order@mohrsiebeck.com

Telefon: +49 (0)7071-923-17

Telefax: +49 (0)7071-51104 